
\title{
25 Research Square \\ Giant Lipoma in Superior Vena Cava: A Case Report and Literature Review
}

\section{Tri Wisesa Soetisna ( $\nabla$ tricts2000@yahoo.com )}

Pusat Jantung Nasional Harapan Kita: Pusat Jantung Nasional https://orcid.org/0000-0002-74283600

\section{Lisca Namretta}

Pusat Jantung Nasional Harapan Kita: Pusat Jantung Nasional

\section{Bagus Ronidipta}

Pusat Jantung Nasional Harapan Kita: Pusat Jantung Nasional

\section{Elen Elen}

Pusat Jantung Nasional Harapan Kita: Pusat Jantung Nasional

\section{Sunu Budhi Raharjo}

Pusat Jantung Nasional Harapan Kita: Pusat Jantung Nasional

\section{Amin Tjubandi}

Pusat Jantung Nasional Harapan Kita: Pusat Jantung Nasional

\section{Research Article}

Keywords: Lipoma, Superior Vena Cava, Intravascular Tumor

Posted Date: May 28th, 2021

DOl: https://doi.org/10.21203/rs.3.rs-542232/v1

License: (c) (1) This work is licensed under a Creative Commons Attribution 4.0 International License.

Read Full License 


\section{Abstract}

Background: Intravascular lipomas were a rare occurrence, especially in major vessels. This tumor is composed of adipocytes in a fibrous capsule that had a slow growth rate and usually shows no symptoms. There were only eight reports in the literature regarding intravascular lipoma located in the superior vena cava.

Case presentation: A 54-year-old man had episodes of supraventricular tachycardia and atrial flutter for over a year. Radiological findings preoperative showed a giant mass that arose from superior vena cava to right atrium and biopsy catheter showed that there were no signs of malignancy. The patient then underwent surgery through a median sternotomy and the mass was extirpated on the highest part of the stalk that could be reached. The patient was stable and remains to show no symptoms or evidence of residual mass or stalk in 2 years follow-up.

Conclusion: The surgical approach in excising lipoma in SVC should be considered wisely with the support of adequate preoperative diagnostic. Extensive manipulation that could increase surgical technique difficulty or postoperative morbidity and mortality is not necessary since lipoma is a very slowgrowing tumor.

\section{Background}

Primary benign tumors that originate from the intravascular wall are considered a rare occurrence. Among all of them, lipomas were found to be extremely rare, especially the ones that occur in superior vena cava (SVC). 1 Currently there were only 30 pieces of literature found on PubMed by using search terms "intravascular lipoma", "superior vena cava lipoma" and "intravenous lipoma". There were only eight cases found regarding intravascular lipoma located in the SVC. ${ }^{2}$

Intravascular lipomas were composed of adipocytes in a fibrous capsule that had a slow growth rate. It usually shows no symptoms that it commonly diagnosed after an incidental finding. ${ }^{3}$ Even though only large-sized of this tumor could cause obstructive symptoms, many had believed that it better be surgically removed due to its probability of causing turbulent blood flow and subsequently thrombotic complication in the venous portal system. ${ }^{4}$

\section{Case Presentation}

A 54-year-old man had episodes of supraventricular tachycardia and atrial flutter for over a year. The patient was an ex-smoker with a history of hypertension, dislipidemia, and a family history of sudden cardiac death. The physical examination results were unremarkable. Transthoracic echocardiography (TTE) examination shows a large mass at right atrium (RA) with the size 4,7 x 3,6 cm, occupy more than half of RA chambers. The left ventricle is normal in size and function, with an ejection fraction of $73 \%$. Other findings in TTE were normal. A computed tomography scan (CT) showed an elongated lesion with low density that arose from SVC to RA (Fig. 1a). Magnetic resonance imaging (MRI) examination 
confirmed a big capsulated mass that arose from SVC to RA with the size of $12 \times 4 \times 4 \mathrm{~cm}$ (Fig. 1b). The mass was confirmed as a fat-rich content and diagnosed as lipoma. Given the size and patient's age, malignancy could not be excluded. Therefore the patient underwent biopsy by catheterization and the results showed that there were no signs of malignancy. The patient was prepared for extirpation and underwent catheterization. It was found that the left main artery had $20-30 \%$ stenosis on the distal, left anterior descending artery had $40-50 \%$ stenosis on the middle, left circumflex artery had $60-70 \%$ stenosis on the distal, and right coronary artery had $50 \%$ discrete stenosis on the proximal. The patient was diagnosed with a moderate 3-vessel disease of the coronary artery, and it was decided to be treated conservatively.

The median sternotomy approach was chosen and we found that SVC was 2 times bigger than the aorta. Under guiding TEE the mass found to be occupied the SVC, then we decided to canulate the internal jugular vein and IVC. Under a total bypass with a cardiopulmonary bypass machine, RA was opened and we found a yellowish mass inside the RA that originate from SVC. The mass has a stalk that origin from the cranial of SVC. The mass was yellowish with the size of $15 \times 5 \times 4 \mathrm{~cm}$, had a lobulated surface, mobile, and had rubbery consistency (Fig. 2). We pulled the mass and extirpated it on the highest part of the stalk that could be reached. RA was closed and cardiopulmonary bypass was quickly discontinued without any problem, and the surgery was done smoothly. The patient was stable with normal sinus rhythm on ECG post-surgery and was discharged four days after.

Pathology examination shows mature white adipose cells with no-centrally located nuclei dominated this mass, thin fibrous septa in some parts, and a few blood vessels. These histologic findings confirmed the mass as lipoma. The patient underwent cardiac rehabilitation program after being discharged and remains to show no symptoms in 2 years follow-up. There is also no evidence of residual mass or stalk on the SVC on Cardiac MRI with four chamber and right ventricle two chamber stack 10 slices, slice thickness $6 \mathrm{~mm}$ that was performed extended to the cervical region on 2 years follow-up (Fig. 3).

\section{Discussion And Conclusions}

Lipomas are benign tumors that rarely occur intraluminal in major vessels, which most prevalent in people between 40-60 years. It usually shows no symptoms, but when present it usually shows obstructive symptoms of cardiovascular like congestiveness and edema. ${ }^{5-6}$ We only found eight cases of SVC lipoma from a literature search in PubMed (Table 1.). Four cases described that patients showed obstructive symptoms. In our case, the patient shows symptoms of periodical arrhythmia which has never been described in other cases even though the one that extended to the right atrium like ours. We assumed that the symptom was due to its position in RA and its gigantic size, therefore we decided not to do any invasive intervention to it. It was confirmed so that the arrhythmia was disappeared after the resection. 
Table 1

\begin{tabular}{|c|c|c|c|c|c|}
\hline $\begin{array}{l}\text { Author } \\
\text { (Year) }\end{array}$ & Gender/Age & $\begin{array}{l}\text { Clinical } \\
\text { Presentation }\end{array}$ & $\begin{array}{l}\text { Prediagnostic } \\
\text { modalities }\end{array}$ & $\begin{array}{l}\text { Tumor } \\
\text { Size }\end{array}$ & $\begin{array}{l}\text { Surgical } \\
\text { Approach }\end{array}$ \\
\hline \multirow[t]{2}{*}{$\begin{array}{l}\text { Vinnicombe } \\
\text { S }(1994)^{10}\end{array}$} & \multirow[t]{2}{*}{ F, 42 y.o } & \multirow[t]{2}{*}{$\begin{array}{l}\text { Fatigue, } \\
\text { edema face } \\
\text { and right hand }\end{array}$} & $\begin{array}{l}\text { CT scan: rounded } \\
\text { mass of fat } \\
\text { compressing } \\
\text { proximal right } \\
\text { brachiocephalic vein } \\
\text { and SVC }\end{array}$ & \multirow[t]{2}{*}{$10 \times 5 \times 5 \mathrm{~cm}$} & \multirow[t]{2}{*}{$\begin{array}{l}\text { not well } \\
\text { described }\end{array}$} \\
\hline & & & $\begin{array}{l}\text { Venogram: large } \\
\text { lobulated filling } \\
\text { defect up to } 3.5 \mathrm{~cm} \\
\text { diameter in SVC }\end{array}$ & & \\
\hline $\begin{array}{l}\text { Thorogood } \\
\text { SV } \\
(1996)^{11}\end{array}$ & M, 73 y.o & Asymptomatic & $\begin{array}{l}\text { CT scan: mass of } \\
\text { fat density in SVC } \\
\text { and the right } \\
\text { braciocephalic vein }\end{array}$ & $\begin{array}{l}\text { not } \\
\text { specified }\end{array}$ & $\begin{array}{l}\text { no surgical } \\
\text { intervention }\end{array}$ \\
\hline \multirow[t]{3}{*}{$\begin{array}{l}\text { Mordant P. } \\
(2010)^{12}\end{array}$} & \multirow[t]{3}{*}{ F, 55 y.o } & \multirow[t]{3}{*}{ Asymtompatic } & $\begin{array}{l}\text { CT scan: } \\
\text { intraluminal } \\
\text { nonenhancing tumor } \\
\text { occluding the distal } \\
\text { right subclavian } \\
\text { vein, the right } \\
\text { brachiocephalic } \\
\text { vein, and the SVC up } \\
\text { to the right atrium }\end{array}$ & $9 \times 6 \mathrm{~cm}$ & \multirow{3}{*}{$\begin{array}{l}\text { median } \\
\text { sternotomy } \\
\text { with right } \\
\text { transclavicular } \\
\text { cervicotomy. } \\
\text { Transverse } \\
\text { venotomy in } \\
\text { SVC. En bloc } \\
\text { resection, end- } \\
\text { to-end } \\
\text { anastomosis } \\
\text { left } \\
\text { innominate } \\
\text { vein - SVC }\end{array}$} \\
\hline & & & $\begin{array}{l}\text { Venogram: total } \\
\text { occlusion of the } \\
\text { right subclavian and } \\
\text { brachiocephalic } \\
\text { veins and of the SVC } \\
\text { to the level of the } \\
\text { azygos vein }\end{array}$ & & \\
\hline & & & $\begin{array}{l}\text { MRI: fatty } \\
\text { intravascular lesion }\end{array}$ & & \\
\hline $\begin{array}{l}\text { Bravi MC } \\
(2011)^{4}\end{array}$ & M, 63 y.o & $\begin{array}{l}\text { Abdominal, } \\
\text { right shoulder, } \\
\text { and lumbar } \\
\text { pain }\end{array}$ & $\begin{array}{l}\text { CT scan: superior } \\
\text { vena caval (SVC) } \\
\text { filling defect with a } \\
\text { subtotal occlusion } \\
\text { that extended into } \\
\text { the right atrium. } \\
\text { MRI: uniform signal } \\
\text { drop on fat- } \\
\text { suppressed }\end{array}$ & $\begin{array}{l}\text { not } \\
\text { specified }\end{array}$ & $\begin{array}{l}\text { not well } \\
\text { described }\end{array}$ \\
\hline & & & sequences & & \\
\hline $\begin{array}{l}\text { Tanyeli O } \\
(2015)^{1}\end{array}$ & M, 48 y.o & $\begin{array}{l}\text { Right arm } \\
\text { edema and } \\
\text { paresthesia }\end{array}$ & $\begin{array}{l}\text { CT scan and MRI: } \\
\text { fat density within } \\
\text { SVC }\end{array}$ & $5 \times 2 \mathrm{~cm}$ & $\begin{array}{l}\text { mini J } \\
\text { sternotomy, } \\
\text { venotomy }\end{array}$ \\
\hline
\end{tabular}




\begin{tabular}{|c|c|c|c|c|c|}
\hline $\begin{array}{l}\text { Author } \\
\text { (Year) }\end{array}$ & Gender/Age & $\begin{array}{l}\text { Clinical } \\
\text { Presentation }\end{array}$ & $\begin{array}{l}\text { Prediagnostic } \\
\text { modalities }\end{array}$ & $\begin{array}{l}\text { Tumor } \\
\text { Size }\end{array}$ & $\begin{array}{l}\text { Surgical } \\
\text { Approach }\end{array}$ \\
\hline \multirow[t]{3}{*}{$\begin{array}{l}\text { Concatto } \\
\mathrm{NH} \\
(2015)^{13}\end{array}$} & \multirow[t]{3}{*}{ M, 58 y.o } & \multirow[t]{3}{*}{ Asymptomatic } & $\begin{array}{l}\text { CT scan: a } \\
\text { hypodense } \\
\text { elongated }\end{array}$ & \multirow[t]{3}{*}{$11 \times 3 \mathrm{~cm}$} & \multirow[t]{3}{*}{$\begin{array}{l}\text { not well } \\
\text { described }\end{array}$} \\
\hline & & & $\begin{array}{l}\text { lesion with fat } \\
\text { density within the } \\
\text { superior vena cava }\end{array}$ & & \\
\hline & & & $\begin{array}{l}\text { MRI: confirmed the } \\
\text { fatty nature of the } \\
\text { lesion }\end{array}$ & & \\
\hline $\begin{array}{l}\text { Wahab A } \\
(2017)^{14}\end{array}$ & F, 70 y.o & Asymptomatic & $\begin{array}{l}\text { TEE: } 2.6 \times 1.6 \times 1.6 \mathrm{~cm} \\
\text { partially obstructing } \\
\text { round, echogenic } \\
\text { mass at SVC and RA } \\
\text { juction }\end{array}$ & $2-3 \mathrm{~cm}$ & $\begin{array}{l}\text { No surgical } \\
\text { intervention }\end{array}$ \\
\hline \multirow[t]{2}{*}{$\begin{array}{l}\text { Sundaram } \\
\mathrm{N}(2020)^{2}\end{array}$} & \multirow[t]{2}{*}{ M, 58 y.o } & \multirow[t]{2}{*}{ Asymptomatic } & $\begin{array}{l}\text { CT scan: } \\
\text { intraluminal } 5 \mathrm{~cm} \\
\text { mass in the right } \\
\text { innominate vein } \\
\text { extending into SVC }\end{array}$ & $5 \mathrm{~cm}$ & \multirow{2}{*}{$\begin{array}{l}\text { median } \\
\text { sternotomy } \\
\text { with right } \\
\text { cervical } \\
\text { extension, } \\
\text { venotomy in } \\
\text { SVC, counter } \\
\text { incision in } \\
\text { right mid- } \\
\text { jugular vein }\end{array}$} \\
\hline & & & $\begin{array}{l}\text { Venous duplex: large } \\
\text { pedunculated } 5 \mathrm{~cm} \\
\text { hyperechoic mass at } \\
\text { the junction of the } \\
\text { right internal jugular } \\
\text { and subclavian } \\
\text { veins }\end{array}$ & & \\
\hline \multirow[t]{2}{*}{$\begin{array}{l}\text { Soetisna } \\
\text { TW. Et al } \\
\text { (2021) }\end{array}$} & \multirow[t]{2}{*}{ M, 54 y.o } & \multirow[t]{2}{*}{$\begin{array}{l}\text { Episodes of } \\
\text { SVT and atrial } \\
\text { flutter }\end{array}$} & $\begin{array}{l}\text { CT scan: elongated } \\
\text { lesion with low } \\
\text { density from SVC to } \\
\text { RA }\end{array}$ & \multirow[t]{2}{*}{$15 \times 5 \times 4 \mathrm{~cm}$} & \multirow[t]{2}{*}{$\begin{array}{l}\text { conventional } \\
\text { median } \\
\text { sternotomy }\end{array}$} \\
\hline & & & $\begin{array}{l}\text { MRI: big capsulated } \\
\text { mass from SVC to } \\
\text { RA (fat-rich content) }\end{array}$ & & \\
\hline
\end{tabular}

None of those eight cases underwent biopsy before the intervention. There were only a few articles about intravascular lipoma and there was no literature that shows the incidents of intravascular lipoma or liposarcoma. Despite it, there were data about the incidence of lipoma and liposarcoma originated from the heart that shows the rarity of the case (lipoma $0.07 \%-8.4 \%$; liposarcoma $0.19 \%-0.5 \%$ ). ${ }^{7}$ Nevertheless the rarity of malignancy incidence in the cardiovascular tumor, we still cannot exclude the possibility of malignancy, in this case, due to its size (the biggest lipoma ever been reported in SVC) and the age of the patient. Studies have shown cardiac MRI to be the gold standard diagnostic imaging modality for cardiac lipoma, but it has limited sensitivity that could only distinguish $69 \%$ of cases in the setting of welldifferentiated liposarcoma. ${ }^{8}$ Given that malignant tumor originated from cardiovascular required different 
consideration in treatment options, therefore we still encourage to do the biopsy before intervention to better weigh the risks and benefit of the surgical treatment.

In our case, the cardiac CT and cardiac MRI didn't specify the origin of the lipoma's stalk; it was fully described by Elen, et al. ${ }^{9}$ Given the uncertainty of the tumor origin, we decided to not performed any extensive manipulation due to its probability of increasing surgical technique difficulty and postoperative morbidity or mortality. Two years after, the patient remains to shows no symptoms, and Cardiac MRI also shows no evidence of recurrence of the tumor or the stalk. This evidence certifies that it is not necessary to do any extensive manipulation or other surgical approaches to reach the origin of the stalk since lipoma is a very slow-growing tumor. Nevertheless, we still encourage to do throughout diagnostic approach before the procedure to define the whole mass' precise location. Extension of cardiac MRI to the cervical region or venography should be considered in any similar cases.

The surgical approach in excising lipoma in SVC should be considered wisely with the support of adequate preoperative diagnostic. Extensive manipulation that could increase surgical technique difficulty or postoperative morbidity and mortality is not necessary since lipoma is a very slow-growing tumor.

\title{
Abbreviations
}

SVC

Superior vena cava; TTE:Transthoracic echocardiography; RA:Right Atrium; CT:Computed tomography; MRI:Magnetic resonance imaging; TEE:Transesophageal echocardiography; IVC:Inferior vena cava; ECG:Electrocardiogram

\section{Declarations}

Ethics approval and constent to participate

\author{
Not applicable.
}

Consent for publication

Informed consent was obtained from the patient.

Availability of data and materials

The datasets used and/or analysed during the current study are available from the corresponding author on reasonable request.

Competing interest

The authors declare that they have no competing interests. 


\section{Funding}

There was no funding for this case report.

\section{Author's contributions}

Tri Wisesa Soetisna: tricts2000@yahoo.com: conceptualized, wrote the paper and reviewed the literature. Lisca Namretta: Iiscanamretta@gmail.com: wrote the manuscript and edited the paper. Bagus Ronidipta: ronipradana@rocketmail.com: reviewed the literature. Elen Elen: elensahara@gmail.com: validated the data and reviewed the paper. Sunu Budhi Raharjo: sunu.b.raharjo@gmail.com: reviewed and edited the paper. Amin Tjubandi: amintjubandi@yahoo.com: supervised, reviewed the literature and edited the paper.

\section{Acknowledgements}

Not applicable.

\section{References}

1. Tanyeli O, Dereli Y, Gormus N, Odev K. Primary Intravascular Lipoma of the Superior Vena Cava. Balkan Med J. 2015;32(3):333-334. doi:10.5152/balkanmedj.2015.15808.

2. Sundaram N, Kulkarni R, Sultan I, Singh M. Surgical Resection of a Symptomatic Superior Vena Cava Lipoma: A Case Report and Literature Review. Ann Vasc Surg. 2021;71:535.e11-535.e15. doi:10.1016/j.avsg.2020.09.052.

3. Doyle Z, Wolford B, Morshedi M, Santillan C. Intravascular lipoma of the renal vein. BJR/case reports. 2015;1(2):20150072. doi:10.1259/bjrcr.20150072.

4. Bravi M, Salvadei S, Scarponi P, Loforte A, Musumeci F, Gasbarrone L. Intravascular lipoma of the superior vena cava. Intern Emerg Med. 2011;7(1):79-81. doi:10.1007/s11739-011-0584-9.

5. D'Souza J, Shah R, Abbass A, Burt J, Goud A, Dahagam C. Invasive Cardiac Lipoma: a case report and review of literature. BMC Cardiovasc Disord. 2017;17(1). doi:10.1186/s12872-016-0465-2.

6. Ismail I, Al-Khafaji K, Mutyala M, Aggarwal S, Cotter W, Hakim H, Khosla S, Aora r. Cardiac Lipoma. J Community Hosp Intern Med Perspect. 2015;5(5):28449.

7. Amano J, Nakayama J, Yoshimura Y, Ikeda U. Clinical classification of cardiovascular tumors and tumor-like lesions, and its incidences [published correction appears in Gen Thorac Cardiovasc Surg. 2013 Aug;61(8):448]. Gen Thorac Cardiovasc Surg. 2013;61(8):435-447. doi:10.1007/s11748-0130214-8.

8. O'Donnell PW, Griffin AM, Eward WC, et al. Can Experienced Observers Differentiate between Lipoma and Well-Differentiated Liposarcoma Using Only MRI?. Sarcoma. 2013;2013:982784. doi:10.1155/2013/982784.

9. Elen E, D'Angelo T, Tjubandi A, Raharjo S. A rare case of superior vena cava lipoma: its presentation from non-invasive examination. European Heart Journal - Cardiovascular Imaging. 
2019;20(10):1183-1183.

10. Vinnicombe S, Wilson A, Morgan R, Saunders K. Intravascular Lipoma of the Superior Vena Cava. Journal of Computer Assisted Tomography. 1994;18(5):824-827.

11. Thorogood S, Maskell G. Intravascular lipoma of the superior vena cava-CT and MRI appearances. The British Journal of Radiology. 1996;69(826):963-964.

12. Mordant P, Mercier O, Fadel E, Muniappan A, Fabre D, Chataigner $O$ et al. Surgical resection of an intravascular superior vena cava primary lipoma. The Journal of Thoracic and Cardiovascular Surgery. 2010;140(6):1437-1438.

13. Concatto N, Camargo S, Camargo J, Hochhegger B, Irion K, Marchiori E. Superior Vena Cava Lipoma in an Asymptomatic Man. Lung. 2015;193(5):847-849.

14. Wahab A, Chaudhary S, Munir A, Smith S. Lipoma of superior vena cava: a rare occurrence. BMJ Case Reports. 2017;::bcr-2017-220641.

\section{Figures}
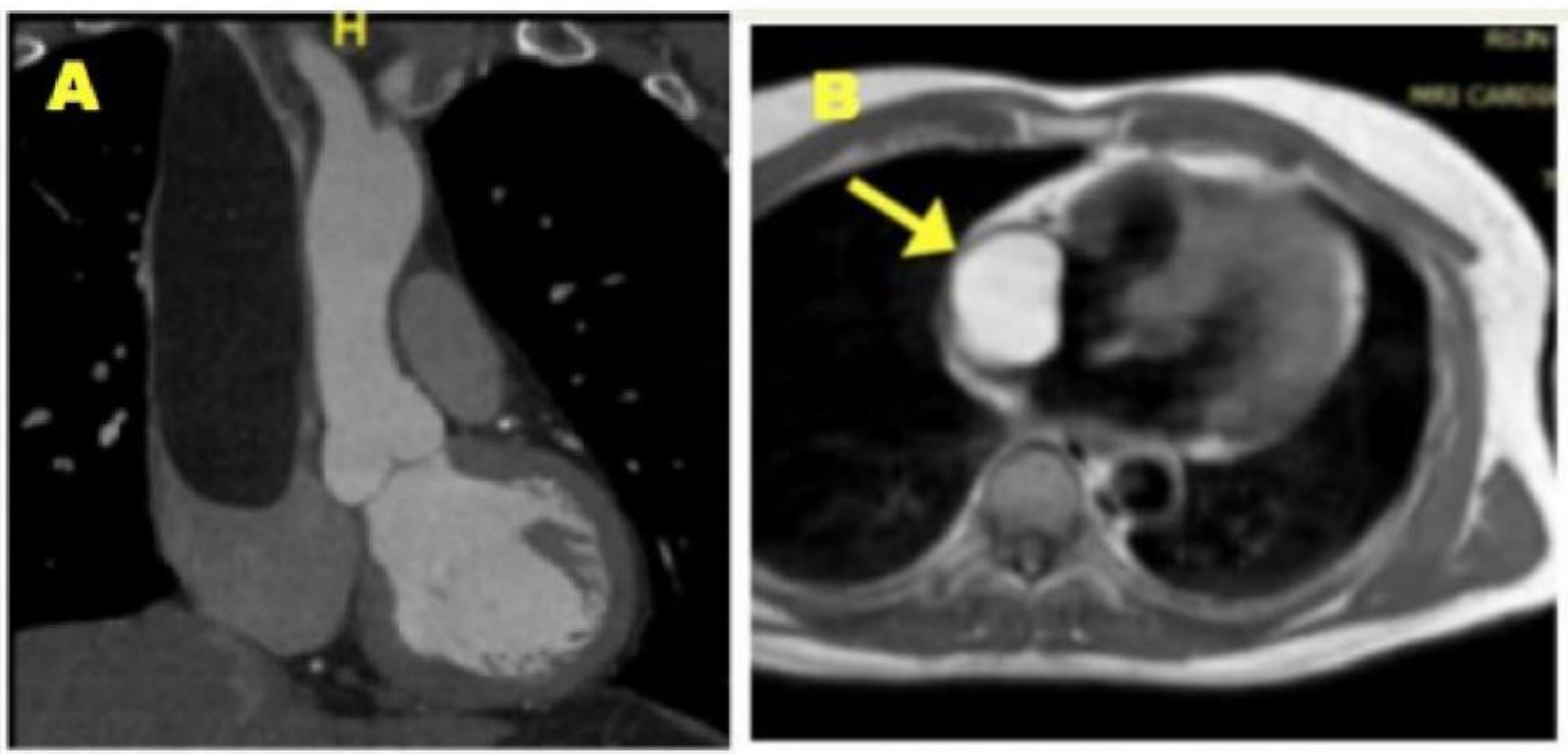

\section{Figure 1}

Preoperative radiology. (a) CT scan coronal plane; (b) Cardiac MRI T1-weighted image axial plane. 


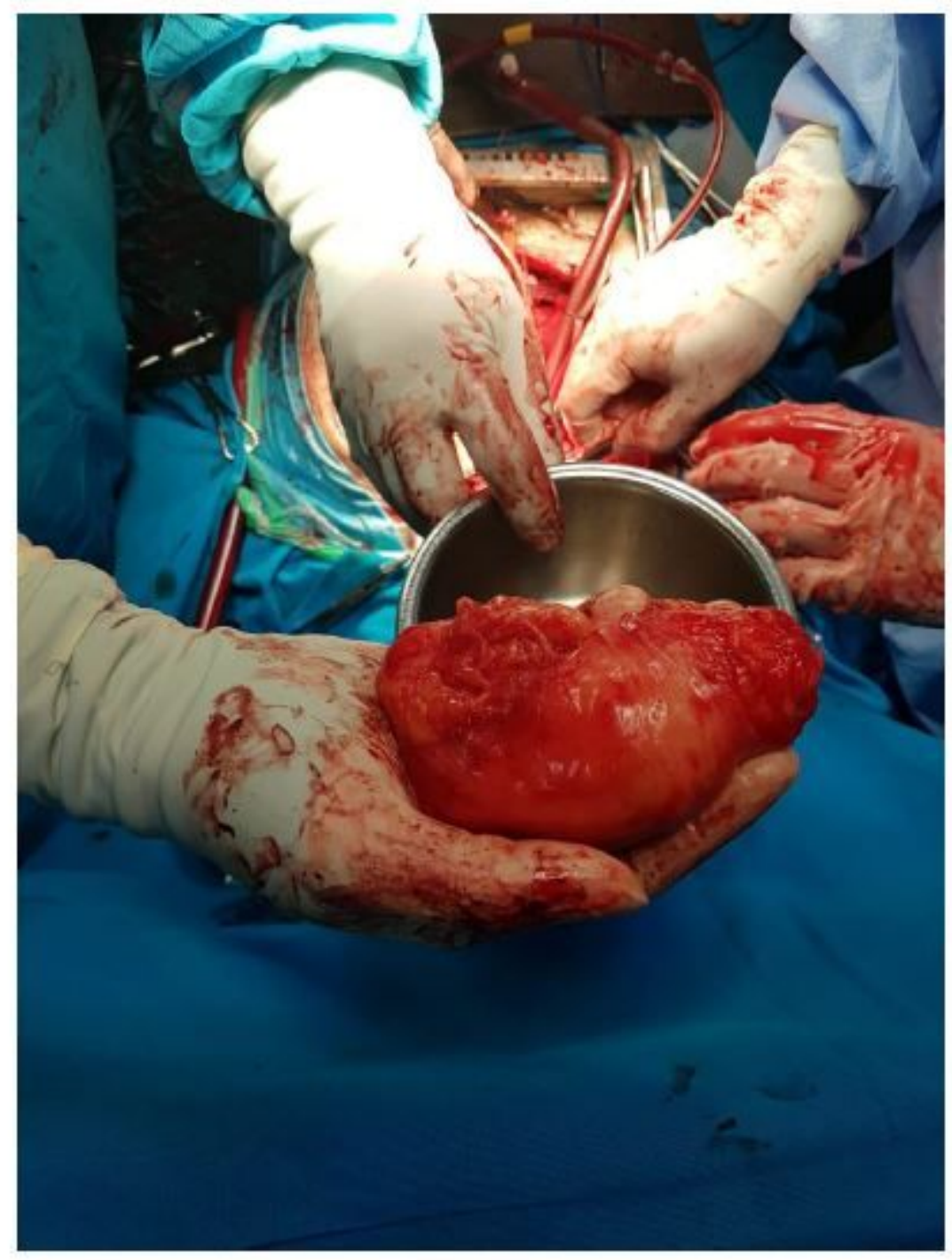

Figure 2

Giant lipoma after surgically resected 


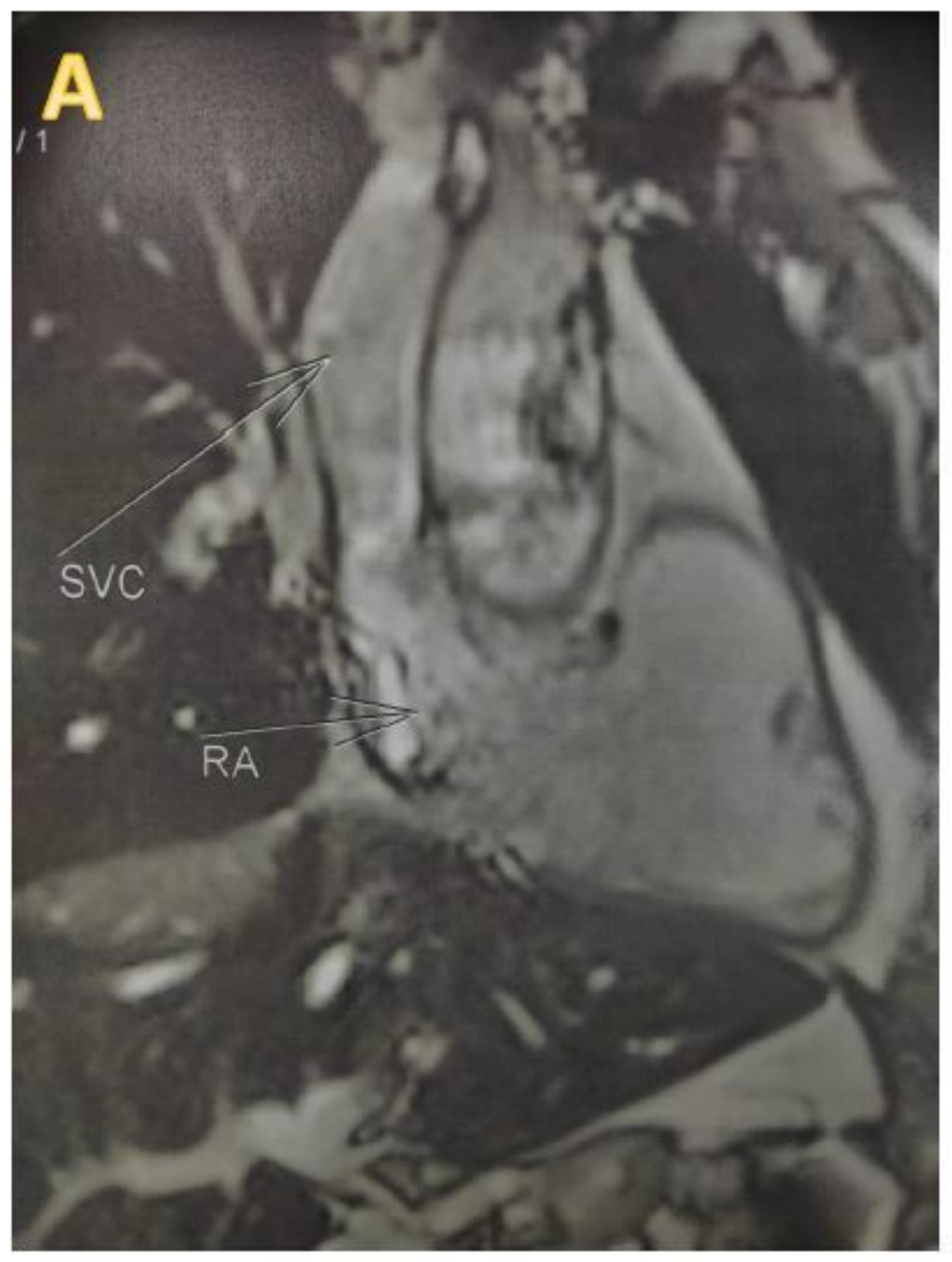

Figure 3

year post operatif cardiac MRI (cMRI). (a) Cine cMRI coronal plane; (b) Cine cMRI axial plane. 